IRA-International Journal of Education \& Multidisciplinary Studies ISSN 2455-2526; Vol.05, Issue 02 (2016)

Pg. no. $119-128$

Institute of Research Advances

http://research-advances.org/index.php/IJEMS

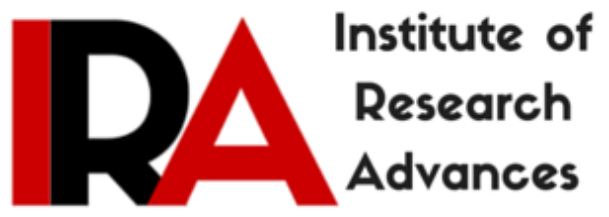

\title{
Inclusive Teaching-Learning Strategies to Meet Academic Needs of Learners with Special Needs in Kenya (A Case of Kakamega East Sub-county)
}

\section{Otundo Denis Tsisindu}

Daisy Special School, Kakamega.

P.O Box 2261-50100, Kakamega, Kenya.

\section{Okutoyi Joel}

Department Of Special Needs Education,

Maseno University., P.O Box 333, Maseno, Kenya.

\section{Khasakhala Edward}

School of Education, Mt.Kenya University,

Kakamega Campus, P.O Box 553- 50100, Kakamega, Kenya.

Type of Review: Peer Reviewed.

DOI: http://dx.doi.org/10.21013/jems.v5.n2.p7

\section{How to cite this paper:}

Tsisindu, O., Joel, O., \& Edward, K. (2016). Inclusive Teaching-Learning Strategies to Meet Academic Needs of Learners with Special Needs in Kenya (A Case of Kakamega East Sub-county). IRA International Journal of Education and Multidisciplinary Studies (ISSN 2455-2526), 5(2), 119-128. doi:http://dx.doi.org/10.21013/jems.v5.n2.p7

(C) Institute of Research Advances

(c) EY-NC

This work is licensed under a Creative Commons Attribution-Non Commercial 4.0 International License subject to proper citation to the publication source of the work.

Disclaimer: The scholarly papers as reviewed and published by the Institute of Research Advances (IRA) are the views and opinions of their respective authors and are not the views or opinions of the IRA. The IRA disclaims of any harm or loss caused due to the published content to any party. 


\begin{abstract}
The national education system has been characterised by inadequate educational management practices and facilities that do not respond well to the challenges faced by Learners with Special Needs (LWSNs). These learners are gradually and deliberately pushed out of the school system because schools are not sensitive to their learning styles and background. The purpose of this study was therefore to assess the extent to which inclusive teaching-learning strategies were employed to meet academic needs of learners with special needs in public primary schools in Kakamega East Sub-county. The study objective was to; determine the extent to which the teaching and learning strategies were employed to meet the academic needs of learners with special needs in primary schools. The study was based on the theory of Normalisation and it made use of the descriptive survey research design. The target population was 90 head teachers, 999 teachers and one Educational Assessment and Resource Centre (EARC) coordinator. The schools were stratified according to zones and simple random sampling was used to select, 18 head teachers and 200 teachers, while the EARC coordinator was selected by the purposive sampling technique. Instruments for data collection were the questionnaires, interview schedules and document analysis. Content validity was used to determine the validity of the research instruments while the test-retest method was used to test reliability using the Pearson Product moment of correlation coefficient $(r)$ value. Data was then analysed using both descriptive and inferential statistics and the results were presented in form of frequency tables. The research findings revealed that teachers lack relevant skills to meet the academic needs of LWSNs and they rarely address learners' needs through the individualised education programmes (IEP). The researcher recommended that regular inspections should be carried out in schools as a follow up measure of ensuring that inclusive education and its management practices are implemented to the latter. Teachers who are not trained in special needs education (SNE) should be given an opportunity to undergo training so as to equip them with the necessary skills and attitudes towards LWSNs. IEP need to be developed for every learner with specialneeds in learning, learners with special needs need to be involved in class activities.
\end{abstract}

Key words: Teaching-Learning Strategies, Learners with Special Needs, Special Education

\title{
Background to the Study
}

Benoit (2013), on an overview of the education system in Kenya, indicated that despite all the recommendations sited above, the implementation of inclusive education and its management practices is moving at a very slow pace. This is because the process is hindered by vague guidelines that describe the implementation of an inclusive policy, insufficient data on children with special needs (CWSNs), ineffective assessment tools, curriculum, and a lack of qualified professionals.

The Disability Act of 2003 provides a comprehensive legal framework, which outlaws all forms of discriminative treatment of PWDs. Article 18(1) of this act states that: "No person or learning institution shall deny admission of a person with a disability to any course of study by reason only of such disability, if the person has the ability to acquire substantial learning in that course". This gives an opportunity to PWDs to access education and participate as equal members of society.

On the other hand, the children's Act of 2001 harmonizes all the existing laws and policies on children into one document and aims at improving the well being of all children irrespective of whether they are disabled or not. The Gender Policy on Education of 2001 singles out education for LWSNs, and goes further to stress that the government should provide an enabling environment through flexing the curriculum, providing trained personnel, equipment and facilities and ensuring accommodative physical infrastructure for LWSNs.

Current teachers are the real implementers of inclusive education and its management strategies and as such, they have to be supported and trained continuously. Inclusive schools must recognize and respond 
to the diverse needs of their learners, accommodating both different styles of learning and ensuring quality education to all through appropriate curricula, organizational arrangements, teaching strategies, resource use and partnerships with their communities (UNESCO, 2006).

Ngugi (2002) noted that, inadequate educational facilities, poor and rigid teaching approaches, overloaded and expensive curriculum, rigid assessment procedures based on mean score competition which does not consider LWSNs are poor teaching and learning strategies that impact negatively on effective implementation of inclusive education and its management practices. Ngugi (2002) therefore further recommended that curriculum diversification, adaptation of examinations and alternative ways of measuring learners' competence are teaching and learning strategies that will promote inclusion in education.

Inadequate resources are yet another factor that impact negatively on the implementation of inclusive education management.Hay et al (2002) emphasized that teacher preparedness for inclusive education depends on the high quality of professional preperation of teachers at pre and in-service level to equip them for and update their knowledge in meeting the needs of a diverse classroom population. Antia et al (2002) noted that Inclusive education also requires close collaboration between regular class teachers and a range of other people that is working in collaboration with other service providers with an aim of addressing the diverse needs of LWSNs.

According to a study by Booth et al (2000) on developing learning and participation in school, the following conditions demonstrate that learning effectively revolves around inclusion and its management practices. These conditions are; Lessons are responsive to learning diversity; Learners are actively involved in their own learning, Learners are taught by other learners during free time, Teachers assist through the individualised education programme, Teachers' expectations are realistic and based on recognition of their strengths and weaknesses, the curriculum, activities, materials and equipment are adapted and modified so as to suit learners' needs and learners are given extra instruction time when neccessary.

In addition, Ngugi (2002) noted that, other teaching and learning resources in an inclusive setting include, observation by teachers of preferential sitting arrangement for LWSNs in the classroom setting, teaching/learning activities should focus on the needs of the whole child rather than focusing on measurable out comes, there are adequate assistive devices, LWSNs are given additional time during both internal and external examinations, Parents of LWSNs participate in evaluation and placement decisions for their children and that all learners take part in activities outside the classroom.

Booth et al (2000) further noted that, indicators for mobilising teaching and learning resources include; utilization of Community resources; full exploitation of Staff expertise and using learner differences as a resource for teaching. When attention is paid to learning that is effectively orchestrated, the focus shifts to inclusive measures that move beyond the classroom walls to include the acquisition of learning support materials outside the physical environment of the classroom.

Mobilisation of resources also constitutes of, practitioners, ranging from private medical and paramedical practitioners, such as psychologists and therapists, to primary health care workers employed by NGOs or Disabled People's Organisations. Teachers should aim at making LWSNs realise that they have something unique to offer and which should be seen as a resource in itself.

The implementation of free primary education (FPE) in 2003 which was a move to realize the Millennium Development Goals, led to an influx and inclusion of new categories of LWSNs in public schools apart from the four traditional disability areas. This therefore led to increased demands from parents and teachers and overstretched the ministry's resource. The varying categories of disabilities and the range in 
severity in our educational institutions have resulted to emergence of a continued debate on the viability of inclusive education (MOE, 2009).

\section{Statement of the problem}

In as much as Kenya is embracing the philosophy of inclusion and even gone further and formulated a national policy framework on SNE, the national education system has been characterised by inadequate educational management structures and facilities that do not respond well to the challenges faced by LWSNs (Ministry Of Education, 2009). In Kakamega East Sub-county, out of the total enrolment of 47,754 learners in public primary schools, 4720 are LWSNs (Education Office - Kakamega East Subcounty, 2014). This is in conformity with the WHO assertion that $10 \%$ of a given population comprises Persons With Disabilities. In Kakamega East Sub-county, cases of dropouts, repetition of classes, poor academic performance among learners with special needs, and use of teaching-learning strategies has been reported to be on increase. The rights of these learners to acquire basic education and progress further academically are violated since they are gradually and deliberately pushed out of the school system. It was unknown how the extent to which teaching-learning strategies was employed to meet the academic needs of learners with special needs in Kakamega East sub-county, Kenya.

Therefore, this necessitated the present study on extent to which teaching-learning strategies were employed in public primary schools to meet the academic needs of learners with special needs in Kakamega East sub-county, Kenya.

\section{The Purpose of the Study}

The purpose of this study was to determine the extent to which teaching-learning strategies were employed in public primary schools to meet the academic needs of learners with special needs in Kakamega East sub-county, Kenya.

\section{Objectives of the Study}

The study objectives were to;

1. Determine the extent to which teaching-learning strategies are employed by teachers to meet the academic needs of Learners with special needs in public primary schools in Kakamega East Subcounty, Kenya.

\section{Research Methodology}

The study employed descriptive survey research design. The target population was 90 head teachers, 999 teachers and one Educational Assessment and Resource Centre (EARC) coordinator. The schools were stratified according to zones and simple random sampling was used to select, 18 head teachers and 200 teachers, while the EARC coordinator was selected by the purposive sampling technique. Instruments for data collection were the questionnaires, interview schedules and document analysis. Content validity was used to determine the validity of the research instruments while the test-re-test method was used to test reliability using the Pearson Product moment of correlation coefficient (r) value. Quantitative data was analysed using both descriptive statistics such as frequency counts and percentages; and inferential statistics such as multiple standard regression and the results were presented in form of frequency tables. Qualitative data was analysed thematically.

\section{Results and Discussion}

To find out the teaching and learning strategies put in place by teachers to meet the academic needs of LWSNs in public primary schools, teachers were asked to respond to a 14 item scale ranging from 'not at all' to always. The responses were tabulated in frequency counts and percentages as shown in Table 1. 
Table 1: Teaching and Learning Strategies

\begin{tabular}{|c|c|c|c|c|c|c|c|}
\hline Teaching And Learning Strategies & $\begin{array}{l}\text { Not at all } \\
\text { f }(\%)\end{array}$ & $\begin{array}{l}\text { Rarely } \\
\text { f }(\%)\end{array}$ & $\begin{array}{l}\text { Often } \\
\text { f }(\%)\end{array}$ & $\begin{array}{l}\text { Very } \\
\text { often } \\
\text { f }(\%) \\
\end{array}$ & $\begin{array}{l}\text { Always } \\
(\%)\end{array}$ & $\begin{array}{l}\text { Mea } \\
\text { n }\end{array}$ & Std \\
\hline $\begin{array}{l}\text { LWSNs have special classes to address } \\
\text { their special needs }\end{array}$ & $104(52.0)$ & $28(14.0)$ & $24(12.0)$ & $12(6.0)$ & $32(16.0)$ & 2.2 & 1.51 \\
\hline $\begin{array}{l}\text { LWSNs are taught by other learners } \\
\text { during free time }\end{array}$ & $68(34.0)$ & $56(28.0)$ & $28(14.0)$ & $12(6.0)$ & $36(18.0)$ & 2.46 & 1.46 \\
\hline $\begin{array}{l}\text { Teachers have no time to listen to } \\
\text { LWSNs and therefore redicle them }\end{array}$ & $100(50.0)$ & $60(30.0)$ & $28(14.0)$ & $12(6.0)$ & $0(0.0)$ & 1.82 & 1.07 \\
\hline $\begin{array}{l}\text { Teachers assist LWSNs through the } \\
\text { individualised education programme }\end{array}$ & $52(26.0)$ & $60(30.0)$ & $40(20.0)$ & $24(12.0)$ & $24(12.0)$ & 2.54 & 1.32 \\
\hline $\begin{array}{l}\text { LWSNs are labelled by their teachers and } \\
\text { peers }\end{array}$ & $76(38.0)$ & $36(18.0)$ & $52(26.0)$ & $20(10.0)$ & $16(8.0)$ & 2.32 & 1.29 \\
\hline $\begin{array}{l}\text { Teachers' expectations of LWSNs are } \\
\text { realistic and based on recognition of their } \\
\text { strengths and weaknesses }\end{array}$ & $28(14.0)$ & $40(20.0)$ & $52(26.0)$ & $36(18.0)$ & $44(22.0)$ & 3.14 & 1.35 \\
\hline $\begin{array}{l}\text { The curriculum, activities,materials and } \\
\text { equipment are adapted and modified so } \\
\text { as to suit learners' needs. }\end{array}$ & $56(28.0)$ & $52(26.0)$ & $36(18.0)$ & $16(8.0)$ & $40(20.0)$ & 2.66 & 1.47 \\
\hline $\begin{array}{l}\text { LWSNs are given extra instruction time } \\
\text { when neccessary }\end{array}$ & $68(34.0)$ & $48(24.0)$ & $40(20.0)$ & $32(16.0)$ & $12(6.0)$ & 2.36 & 1.26 \\
\hline $\begin{array}{l}\text { The teaching/learning activities focus on } \\
\text { the needs of the whole child }\end{array}$ & $60(30.0)$ & $40(20.0)$ & $36(18.0)$ & $36(18.0)$ & $28(14.0)$ & 2.66 & 1.43 \\
\hline $\begin{array}{l}\text { Classroom discipline is based on mutual } \\
\text { respect for all learners }\end{array}$ & $28(14.0)$ & $52(26.0)$ & $36(18.0)$ & $28(14.0)$ & $56(28.0)$ & 3.16 & 1.44 \\
\hline $\begin{array}{l}\text { There are adequate assistive devices that } \\
\text { are used by LWSNs }\end{array}$ & $104(52.0)$ & $36(18.0)$ & $28(14.0)$ & $24(12.0)$ & $8(4.0)$ & 1.98 & 1.23 \\
\hline $\begin{array}{l}\text { LWSNs are given additional time during } \\
\text { both internal and external examinations }\end{array}$ & $60(30.0)$ & $64(32.0)$ & $12(6.0)$ & $24(12.0)$ & $40(20.0)$ & 2.6 & 1.51 \\
\hline $\begin{array}{l}\text { Parents of LWSNs participate in } \\
\text { evaluation and placement decisions for } \\
\text { their children }\end{array}$ & $64(32.0)$ & $52(26.0)$ & $32(16.0)$ & $28(14.0)$ & $24(12.0)$ & 2.48 & 1.38 \\
\hline
\end{tabular}


From the results in table 1, the overall mean of 2.49 and standard deviation of 1.36 indicates that the teaching/learning strategies are not effective towards the implementation of inclusive education and its management practices. In fact majority of the teachers, 104(52.0\%) stated that LWSNs do not at all have special classes to address their special needs.

A good percentage 100(50.0\%) also stated that teachers do not at all have time to listen to LWSNs and attend to their needs. The curriculum, activities,materials and equipment are also not at all adapted and modified so as to suit learners' needs as stated by 56(28.0\%) of the respondents and supported by 52(26.0\%) who found out that they are rarely adapted. These results are not consistent with Ngugi(2002) findings that curriculum diversification, adaptation of examination and alternative ways of measuring learners competence are teaching and learning strategies that will promote inclusion in schools.

The Mutiple standard regression, as shown in table 1 revealed that teaching and learning strategies was also a unique predictor of effective management staregies. This implies that effective inclusive education management practices would better be reflected through teaching and learning strategies. The magnitude of the effect was high, $(\beta=.465, \mathrm{p}<.05)$.

The results implied that a great variation in the measurement of the change of management practices into better practices would be caused by a reflection in better teaching and learning strategies. However, management practices were not up to the standards of bringing the students with disabilities into a better class.

The interview schedule with the EARC coordinator revealed that there is lack of improvement as far as the implementation of inclusive education management practices are concerned due to the current teaching learning strategies in our learning institutions.

The EARC noted that,

LWSNs do not benefit academically from our learning institutions full of educational management systems that offer overloaded curriculum which is characterised by rigid assessment procedures based on mean score competition. These are poor strategies that reflect lack of adoption of the required management practices initially put in place. But we are assessing them to find a solution

These results are not in tandem with Ngugi (2002) who recommended that curriculum diversification and adaptation of examinations are teaching and learning strategies that will promote inclusion in education. Instead, the schools still base on mean scores in subject despite rigidity in their curriculum. It is therefore clear that the teaching learning strategies put in place have not been effective.

\section{Conclusions and Recommendations}

The results indicated that teachers were not supported and trained continuously to implement inclusive education and its management practices and thus the approach they use to accommodate learners with special needs was not an appropriate method. This was reflected by thier unpreparedness to listen to learners with special needs, teachers did not have time to listen to them and therefore redicle them, the teachers did not recognise and respond to the diverse needs of their learners. LWSNs have no special classes to address their special needs as reported by 104 (52.0\%) of the teachers. Another aspect of poor 
management practices was lack of involvenment of parents of Learners with special needs to participate in evaluation and placement decisions for their children. The overall mean of 2.8 and standard deviation of 1.38 indicates that the teaching-learning strategies were not effective towards the implementation of inclusive education.

\section{Recommendations}

Based on the findings of the study, the study recommends that;

For inclusive practices to be effective in teaching-learning strategies, teachers need to invole learners with special needs in class activities, parents be involved in school activities involving learners with special needs, extra time be provided for learners with special needs to complete assignments, an individualised educational programme be developed for learners with special needs in each class. In addition, learners with special needs be taught special subjects such as Braille and Kenya sign language to enhance their communications skills in classs. Teachers need to be inserviced how to handle learners with special needs in class.

\section{REFERENCES}

Adoyo, P. (2005).Educating Deaf Children in an Inclusive Setting In Kenya, Challenges And Considerations.

Africa Population \&Health Research Centre,(2013). Primary School Completion and Grade Repetition Among Disadvantaged Groups: A Challenge to Achieving UPE by 2015.http://www.aphrc.org

Agbenyega, J. (2006). Examining Teachers' Concerns and Attitudes to Inclusive Education in Ghana.

Ainscow, E. (2006). Improving Schools, DevelopingInclusion.New York: Routledge.

Antia, S.D., Stinson,M.S., \& Gaustad, M.G. (2002). Developing membership in the education of deaf and hard-of-hearing students in inclusive settings.Journal of Deaf Studies and Deaf Education, 7, 214-229.

Baxter, C., Ward, L., Poonia, K. \& Nadirshaw,Z. (1990).Double Discrimination: Issues and Services for People with learning Difficulties from Black and Ethnic Minority Communities London, King's Fund/Commission for Racial Equality.

Bennett, T., DeLuca, D., Bruns, D. (1997).Putting inclusion into practice: Perspectives of teachers and parents. Exceptional Children, 64(1), 115-131.

Benoit, L. (2013). An Overview of the Kenyan Education System: Issues and Obstacles to Learning Canadian International Agency.

Booth, R., Ainscows, M., Black, K., Voughem, M.,\& Shawl, K. (2000).Index for Inclusion; developing learning and participation in school.Bristol: CSIE (2000).

Cooper, D.R.\&Schindler, P.S.(2003). Business Research Methods.Wittenberg University. 
Corbett, J.,\& Slee, R.(2000). "Introduction: What is this Book about?" Inclusive Education: Policy, Contexts and Comparative Perspective.Eds. Felicity Armstrong, Derrick Armstrong, and Len Barton. Great Britain: David Fulton Publishers Ltd.

Creswell, J. (2003). Research design: Qualitative, quantitativeand mixed methodsapproach. Thousand Oaks, California: Sage Publications

Culham, A. (2003). "Deconstructing Normalisation: Clearing the Way for Inclusion."

Journal of Intellectual \& Development Disability 28.1 (2003): 65-78. Print.

Fletcher, A. (2004). Stories of Meaningful Student Involvement. Olympia, Washington

Forlin, C.(2010). Developing and Implementing Quality Inclusive Education in Hongkong:Implications for Teacher Education. International Journal of SpecialEducation 177-184.

Gichana, P.M. (2009). Challenges Facing the Implementation of IE programme in

Public Primary schools in Mombasa District UoN Unpublished report.

Harding, K.A., \& Darling.C.A. (2003). Understanding inclusion: The perspectives of family and consumer sciences teachers. Journal of Family and Consumer Sciences, 95(1), 38- 46.

Huddleston, T. (2007).From Student Voice to Shared Responsibility:Effective Practice in Democratic School Governance in EuropeanSchools. London: Citizenship Foundation.

Jha, M. (2002). School Without Walls: Inclusive Education for All. Oxford: Heinemann

Kaikkonen, L. (2010). Promoting teacher development for diversity. In Rose R. (Ed.), Confronting obstacles to inclusion: International responses to developing inclusive education (pp. 155-169). London, England: Routledge.

Killoran, I. (2002).A Road Less Travelled: Creating A Community Where each Belongs. Childhood Education: 371.

Kochung, E. (2003). Report of the Taskforce on Special Needs Education: Appraisal Exercise, Nairobi, Kenya (MOEST)

Kombo, D.K., \& Tromp, D.L. (2006).Proposal and Thesis writing: An Introduction. Nairobi: Pauline publications Africa.

Macfarlane, A.H. (2007). Discipline, democracy and diversity: working with students with behaviour difficulties. Wellington: New Zealand Council for Educational Research.

Mackenzi, P.M. (2010). Health \& safety in our schools. Nairobi:Rinny Educational \& Technical Publishing Services

Mittler, P. (2002). Educating pupils with intellectual disabilities in England: thirty years on.International Journal of Disability, Development and Education, 49(2), 145-160.

Ministry of Education, (2009).National Special Needs Education Policy Framework. Government Printer, Nairobi. 
Mitchell, D. (2007). What really works in special and inclusive education: Using evidence-based teaching strategies.London: Routledge

MOEST, (2005).Sessional Paper No. 1 of 2005 on Policy Framework for Education, Training and Research. Nairobi: Government Printer.

Mugenda, O.M., \& Mugenda, A. G. (2003).Research methods:Quantitative andqualitative approaches. Nairobi: ARTS Press

Mpya, G. (2010). Managing Inclusive Education in the Classroom.Nkangala:

Mpumangala Educator.

New Brunswick Community of Living, (2011).Creating an Inclusive School. A Reflection Tool forAdministrators,Educators and Other school staff. New Brunswick: New BrunswickAssociation of Community Living.

Ngugi M.W. (2002). Special Needs Education (SNE) Module 1: Introduction to Inclusive Education: Nairobi, KISE.

Norris, B.D. (2001). Transformation, diversity and organisationalchange within institutions of higher education. South AfricanJournal of Education, 21(4):219-225.

Okumbe, J. A. (2007).Education Management: Theory and Practice, Nairobi: University of Nairobi.

Oliver, M. (1999). Capitalism, disability and ideology: A materialist critique of the normalization principle. In R.J. Flynn, \& R. A. Lemay (Eds.), A quarter-century of normalization and social role volarization: Evolutionand impact (pp. 163-174). Ottawa: University of Ottawa Press.

Orodho A. J.,\& Kombo.(2002). Essentials of Education and Social Science Research Methods. Nairobi:Masola Publishers.

Oyugi, L.(2011). Inclusive Education in Kenya: Perspectives of Special Educators. Lap Lambert Academic Publishing: (2011-12-19)

Peters J. Susan. (2004). Inclusive Education; AnEfa Strategy for All Children. World Bank.

Randiki,F.O. (2002).Special Needs Education; Historical Development of Special Needs Education, Nairobi, KISE.

Rayner, S. 2007. Managing Special and Inclusive Education. London: SAGE.

Rea, P.J., Virginia, L.M., \& Chriss, W. (2002). "Outcomes for Students with Learning Disabilities in Inclusive and Pullout Programs." Exceptional Children 68.2 (Winter 2002): 203. Print.

Republic of Kenya.(1988). Report of The Presidential Working Party On Educationand Manpower Training for the Next Decade and Beyond. Nairobi: Government Printer.

Republic of Kenya. (1999). Totally Integrated Quality Education and Training -TIQET: Report of The Commission of Inquiry into The Education System of Kenya. Nairobi: Government Printer.

Republic of Kenya. (2002). The Children Act, 2001. Nairobi: Government Printer.

Republic of Kenya. (2003). The Disability Act, 2003. Nairobi: Government Printer.

Republic of Kenya.(2003). Report of Task Force on Implementation of FreePrimary Education.Nairobi: Government Printer, Nairobi. 
Republic of Kenya. (2005). Kenya Education Sector Support Programme 2005 - 2010. Delivering Quality Education and Transiting to all Kenyans.Government printer, Nairobi.

Republic of Kenya. (2013). The Basic Education Act, 2013. No. 14 of 2013, Nairobi: Government Printer. Republic of Kenya. (2010). Population and Housing Census 2009 - http://www.knbs.or.ke

Salisbury, C.,\& Macgregor, G.(2005). Principals of Inclusive Schools. National Institute for Urban School Development International Journal: University of Montanna.

Saskatchewan, (2001).Creating Opportunities for Students with Intellectual or Multiple Disabilities. Saskatoon, SK: Author.

Shanouda, F. (2010).Are Normalizing Principles Masquerading as Inclusive Education Practices? A working Paper: York University.

The Government of Kenya.(2007). Kenya Vision 2030 - Abridged Version, Nairobi

Thomas, G., \& Loxley, A. (2001).Deconstructing special education and constructing inclusion. Philadelphia: Open University Press

Thuo, Z. W. (2009).Factors Influencing Implementation of IE in regular Primary

Schools in Kiambu West District: UoN Unpublished reports

UN. (2008). Convention on the Rights of Persons with Disabilities: a call for action on poverty, discrimination and lack of access. Report of a Joint Conference organised by Leonard Cheshire Disability and United Nations Economic Commission for Africa, Addis Ababa

UNESCO. (1994). The Salamanca Statement And Framework For Action On Special Needs Education, World Conference On SNE, Access And Quality, Salamanca, Spain UNESCO.

UNESCO. (2000).Open File On Inclusive Education. Paris, UNESCO.

UNESCO, (2002).Gender and Education for All.The Leap to Equality. EFA

Global Monitoring Report 2003/4. Paris: UNESCO.

UNESCO. (2005). Guidelines For Inclusion. Meeting Diversity in Education, Example from Uganda, Paris, UNESCO.

UNESCO.(2008). Barriers to inclusive education. Paris, UNESCO.

UNICEF, (2009).Learning Guide on the Convention on the Rights of Persons with Disabilities

UNICEF, (2010).The Child Friendly Schools Manual, Glen Cove New York.

Valeo, A. (2009). "Education's Enduring Prejudices: Disability at the Door." Learn Inquiry 3: 97-109.

Wamae, G.M \& Kang'ethe, R.W. (2004).The Concept Of Inclusive Education : Teacher TrainingAnd Acquisition Of English Language In The Hearing Impaired.British Journal on Special Education, Volume, 1.

Wolfensberger, W. (1999).An overview of Social role Valorization.In R.J. Flynn \& R.A. Lemay.A Quarter Century of Normalization and Social Role Valorization and Evolution and Impact. Ottawa, ON: University of Ottawa Press.

Yates, S., Dyson, S.,\& Hiles, D.(2008)."Beyond Normalization and Impairment: Theorizing Subjectivity in Learning Difficulties - Theory and Practice." Disability \& Society 23.3 (May 2008): 247-258. Print. 